FACTA UNIVERSITATIS

Series: Mechanical Engineering Vol. 15, N 1, 2017, pp. 145 - 161

DOI: $10.22190 /$ FUME161228007K

Original scientific paper

\title{
IMPLEMENTATION OF THE LEAN-KAIZEN APPROACH IN FASTENER INDUSTRIES USING THE DATA ENVELOPMENT ANALYSIS
}

UDC 519.85:621.7

\author{
Sunil Kumar ${ }^{1}$, Ashwani Kumar Dhingra ${ }^{1}$, Bhim Singh ${ }^{2}$ \\ ${ }^{1}$ Mechanical Engineering Department, University Institute of Engineering \& Technology, \\ Maharshi Dayanand University, India \\ ${ }^{2}$ Mechanical Engineering Department, Sharda University, India
}

\begin{abstract}
This research paper is an attempt to improve the quality system of ten small scale fastener manufacturing industries through the implementation of the Lean-Kaizen approach using the Data Envelopment Analysis (DEA) Charnes Cooper \& Rhodes (CCR) model with constant returns to scale (CRS). Output maximization is taken as the objective function to identify the percentage scope of improvements. The data is collected by paying personal visits to the selected industries for three inputs (manpower, maintenance, and training of employees) and two outputs (quality, on-time delivery) of their quality system. The DEA CCR model is applied to identify efficiency scores of the quality system by taking the most efficient industry as a benchmark for the rest of the organizations. The Lean-Kaizen approach is applied to identify waste / non-value added activities in outputs of the selected industries. Four Kaizen events are proposed to eliminate waste / non-value added activities in their quality system. The data collected after the Kaizen events are further analyzed by the DEA CCR model. The improvements in efficiency scores of the selected industries are presented as findings in this research paper. Two fastener industries became $100 \%$ efficient while the rest of the organizations reported $8 \%$ to $49 \%$ improvements in their efficiency scores of the quality system. The conclusions are made as the Lean-Kaizen using DEA is found to be an effective approach to improve the quality system of fastener industries. This study will be beneficial for researchers, practitioners and academicians for tackling the inefficiencies in the organization.
\end{abstract}

Key Words: Lean-Kaizen, Quality Management System, Brainstorming, Data Envelopment Analysis

Received December 28, 2016 / Accepted February 19, 2017

Corresponding author: Sunil Kumar

Mechanical Engineering Department, University Institute of Engineering \& Technology, Maharshi Dayanand University, India

E-mail: sunil.panchal2007@gmail.com 


\section{INTRODUCTION}

Quality is understood as a measure of excellence or a synonym of zero defects, zero deficiencies or absence of variations in the product by many industries. In order to achieve the desired product quality, the quality system performance is continuously monitored and evaluated for the sake of constant improvements of customer satisfaction, morale and reliability. The adoption of the Lean-Kaizen approach improves the organization output by solving problems through identifying and implementing small improvements in process, product, and system [1-2]. So, the Lean-Kaizen approach is required to be implemented in order to produce quality products by eliminating waste (Muda) in the entire system of the organization [3].

The Lean-Kaizen technique, as a novel one, is composed of two basic words i.e. lean and Kaizen which implies continuous elimination of waste through small-small improvements [4]. It is adopted for waste identification and elimination; it helps industry to be lean [5-6]. It is a systematic way that focuses on continuous improvement of the process, productivity, and quality of the product by suggesting effective and efficient Kaizen events [7]. Leanness can also be defined in terms of efficiency and effectiveness of the manufacturing system [8]. Many methods such as Analytical Hierarchy Process (AHP), Data Envelopment Analysis (DEA) and Fuzzy-Technique for Order Preference by Similarity to Ideal Solution (TOPSIS) are available for measuring performance of the organization. The multiple databases such as a number of employees, maintenance, training of employees, quality, on-time delivery and many other variables of industry make it complex to measure the quality system efficiency. Many analytical tools are available to calculate the efficiency score of the quality system, but DEA is one of the simplest and efficient tools which resolve this complexity more easily and effectively than other alternative methods as it does not perform pair wise comparison (AHP) nor does it require expert system for evaluation (fuzzy-TOPSIS). Some other advantages of DEA as analysis tool [9] are discussed as follows:

- Multiple inputs and outputs (controllable and non-controllable) variables can be easily analyzed to obtain technical efficiency (TE).

- Each decision-making unit (DMU) is compared with other DMUs that provide TE with best-performed DMUs set as the benchmark/peer for each inefficient unit.

- No prior weight of inputs and outputs is required.

- Both strategies such as input minimization and output maximization can be achieved.

Because of these advantages, DEA has been applied to rank many organizations in order to achieve improvements through benchmarking process. In this research paper, the DEA CCR model with CRS is applied to assess the efficiency of quality system of ten small scale industries manufacturing fasteners (producing the same sort of products) by taking three inputs (manpower (no's), maintenance (\%), training of employees (hours)) and two outputs (quality (\%), on-time delivery (\%)) of the quality system. The data is collected by paying a personal visit to the selected industries. The objective function as output maximization is performed in order to identify the possible percentage of improvements in the quality system outputs. The Lean-Kaizen concept is applied in order to identify waste; the Kaizen events are proposed as a solution to eliminate waste in the quality system. After the Kaizen events, the data is collected and further analyzed by the 
DEA CCR model and finally, the improvement in efficiency score of the selected industries is recorded. Two industries scored $100 \%$ efficiency while the rest of them reported $8 \%$ to $49 \%$ improvements in their efficiency scores of the quality system.

\section{LITERATURE REVIEW}

\subsection{Kaizen and lean manufacturing concept}

Continuous Improvement or Kaizen implies those small radical changes or the result of innovative ideas which take place over time without investing huge capital. In 1981, Kaizen is introduced and implemented by Masaaki Imai in Japanese companies to sustain continuous improvement in process, product, and system by focusing on the elimination of waste, defects, variations and deficiencies by the active participation of workforce. It is comprised of two words, i.e. 'Kai' means 'change for' and 'Zen' means 'betterment', simply known as 'Continuous Improvement' or 'Change for the betterment' [10-11]. Kaizen is carried out by trained and skillful employees in order to achieve potential improvements in the quality performance of the organization. Shah and Ward [12] discussed the objectives of a Kaizen in the workshop which make people's jobs easier by taking innovative actions to improve the industry performance. Suarez-Barraza et al. [13] proposed personal Kaizen for individuals to attain improvement in their quality of life. Imai [14] demonstrated Kaizen's umbrella concept to identify the process for reducing waste [15-16]. Taiichi Ohno [17] developed Toyota Production System (TPS) and introduced 'lean' as a process focused on identification and elimination of non-value added activities [18-20] or waste (Muda) in all systems and processes of the organization. The concept got popularized by the famous book "The Machine that changed the world" [21]. Kaizen is building a block of lean thinking [22-25]. Several researchers [26-29] examined the critical success factors for implementation of lean manufacturing and Kaizen within SMEs. Moeuf et al. [30] examined strengths and weaknesses of SMEs regarding the implementation of lean manufacturing and concluded that the absence of functional organization, deficiency of formal procedures and lack of methodology are major difficulties experienced by SMEs during lean implementation. Eaidgah et al. [31] presented a visual framework based on a lean approach to measure performance of management and continuous improvement systems in the manufacturing industry.

\subsection{Lean-Kaizen with DEA}

Lean-Kaizen as a simple improvement technique provides a better scope of improvements which helps to tackle all types of inefficiencies in all types of organizations. It also provides a better understanding for the organizations to take part in achieving their goals and to attain continuous improvements in quality of products [32-33]. The DEA model also helps managers to tune quality system variables in such a way that the entire system will become efficient and effective. Mishra and Patel [34] used the DEA model in supply chain management to improve the level of customer services and attain continuous improvement in process control. Kuah et al. [35] applied DEA as a benchmarking tool to measure and evaluate inefficient areas in quality systems for improvements. Xie et al. [36] applied DEA to measure environmental management efficiency of manufacturing sector. Dabestani et al. [37] used DEA to rank service quality dimensions using importance- 
performance analysis and to compare the outcomes for the customer groups. Lau [38] pointed out that DEA is the most powerful tool to access relative efficiency just as it is more sensitive for consideration of input and output variables. The study concluded that DEA does not provide any guideline to choose these variables for efficiency analysis and hence researchers are free to choose their own inputs and outputs variables. Jafarpour et al. [39] employed DEA for evaluating performance of 30 Esfahan's steel industries based on the suggestion system and concluded that any organization can improve its performance through raising awareness of managers, achieving solutions by suggestion system, through benchmarking, promoting motivation and improving bonus system. Azadeh et al. [40] proposed an integrated approach to simulation and Taguchi method with the DEA model to select an efficient supplier in a closed loop supply chain in which inputs and outputs are selected so effectively as to minimize cost level and maximize a number of highquality products. Warning [41] introduced DEA model as a tool to support employee selection by the human resource department and used the weights assigned by the managers for individual applicants to calculate efficiency scores. Bian et al. [42] proposed centralized DEA and evaluated efficiencies of the parallel systems by shared inputs and outputs. $\mathrm{Wu}$ et al. [43] proposed a two-stage DEA model to evaluate sustainable manufacturing performance by using recycled and re-used waste of Chinese iron and steel industry. Emrouznejad et al. [44] proposed a multiplicative DEA model for ranking forecasting techniques which help forecasters to make a decision for choosing the best forecasting methods in order to minimize waste. Amirteimoori et al. [45] described variable reduction in DEA. In addition, DEA does not demonstrate price information in calculating efficiency score for each DMU; thus it can be appropriately useful for nonprofit organizations where price information is not available. The DEA model has also been successfully applied to evaluate, measure and compare efficiencies in respective fields such as supply chain management [46], power plants [47], vendor selection [48-50], quality circle [51], transportation [52], education system [53], hospitals [54], etc.

After studying referential literature, it is concluded that the application of various lean tools and its associated benefits in industries are well documented in the literature, but very few studies witness the application of Lean-Kaizen concept using DEA.

\section{RESEARCH METHODOLOGY}

The present case study is carried out in ten small scale fastener industries situated in the non-capital region that produces homogenous products for the general market. The DEA CCR model with CRS is selected in order to calculate efficiency score of all selected fasteners industries. The multiple data was collected from the selected industries in which various processes like forging, rolling, heat treatment, plating, final inspection, packing, and dispatch are carefully observed for improvements. The first personal visit is taken for collecting data pertaining to the quality system from all selected DMUs. Selection of inputs and outputs for the DEA model is done on the basis of the mutual coefficient of correlation. Then a DEA model is constructed and efficiency score of the quality system is calculated for all the selected industries by taking the most efficient DMU as a benchmark for the rest of the organizations. The second personal visit is paid to the benchmark industry. All the factors which make the industry efficient and that can be taken as Kaizen events for the inefficient organizations have been noted. In the third 
personal visit, the Lean-Kaizen concept is applied to all inefficient industries in order to eliminate waste and maximize output. In the last and final visit, all the data is recorded for the result analysis and conclusions.

\subsection{Data envelopment analysis (DEA)}

Charnes et al. [55] developed a mathematical programming technique to evaluate the relative efficiency of organizational units known as decision-making units and identify efficient frontier by evaluating input and output set of objects [56-57]. Selected fasteners industries are considered as DMUs. $\mathrm{n}$ is the number of DMUs under analysis and $\mathrm{k}$ is the DMU being assessed from the set of $\mathrm{DMU}_{\mathrm{k}}$ : where $\mathrm{k}=1, \ldots, \mathrm{n}$ DMUs. In this study, $\mathrm{m}=$ number of inputs produce, $s=$ number of outputs, $x_{i k}=$ observed input $i$ at $D_{M U_{k}}: i=$ $1, \ldots, \mathrm{m}, \mathrm{y}_{\mathrm{rk}}=$ observed output $\mathrm{r}$ at $\mathrm{DMU}_{\mathrm{k}}: \mathrm{r}=1, \ldots, \mathrm{s}, \mathrm{u}_{\mathrm{r}}=$ weight of output $\mathrm{r}$ for all, $\mathrm{r}=$ $1, \ldots, \mathrm{s}, \mathrm{v}_{\mathrm{i}}=$ weight of input $\mathrm{i}$ for all, $\mathrm{i}=1, \ldots, \mathrm{m}$.

Efficiency $\mathrm{E}$ of $\mathrm{DMU}_{\mathrm{k}}$ is measured as:

$$
\text { (P1) } \quad E_{k}=\frac{\sum_{r=1}^{s} u_{r} y_{r k}}{\sum_{i=1}^{m} v_{i} x_{i k}}
$$

To maximize the above fractional programming problem (FPP), the mathematical formulation is:

Subjected to:

$$
\text { (P2) } \operatorname{MaxE}_{k}=\frac{\sum_{r=1}^{s} u_{r} y_{r k}}{\sum_{i=1}^{m} v_{i} x_{i k}}
$$

Constraints are:

$$
0 \leq E_{k}=\frac{\sum_{r=1}^{s} u_{r} y_{r k}}{\sum_{i=1}^{m} v_{i} x_{i k}} \leq 1 ; k=1, \ldots ., n
$$

$$
v_{i}, u_{r} \geq 0 ; i=1, \ldots, m ; r=1, . ., s
$$

The objective function (P2) is non-linear and fractional by nature and difficult to solve for TE, but it can be shortened by converting it into linear programming problems (LPP) through normalization of the denominator. The LPP formula is possible by minimizing the weighted sum of inputs, setting the weighted sum of outputs equal to unity. This DEA model refers as a CCR output maximization model with CRS. CRS assumes that returns are constants in the case of the CCR model which simply means that if input increases, the output will increase in the same proportion.

$$
\text { (P3) } \operatorname{MaxZ}=\sum_{r=1}^{s} u_{r} y_{r k}
$$

Subjected to

$$
\sum_{i=1}^{m} v_{i} x_{i k}=1
$$

Constraints

$$
\begin{gathered}
\sum_{r=1}^{s} u_{r} y_{r k}-\sum_{i=1}^{m} v_{i} x_{i k} \leq 0 ; k=1, . ., n \\
v_{i}, u_{r} \geq \mathrm{E} ; i=1, \ldots, m ; r=1, . ., s
\end{gathered}
$$


where $\mathrm{E}$ is an arbitrary small positive number that ensures the positive values of input and output weights. The dual model of the objective function (P3) is derived by assigning dual variables to each constraint.

$$
\text { (P4) } M i n w_{0}-\mathrm{E}\left[\sum_{i=1}^{m} s_{i}^{+}-\sum_{k=1}^{s} s_{i}^{-}\right]
$$

Subjected to

$$
\begin{gathered}
\sum_{k=1}^{n} x_{i k} \lambda_{k}=w_{0} x_{i k}-s_{i}^{+} \\
\sum_{k=1}^{n} y_{r k} \lambda_{k}=y_{r k}+s_{i}^{-} \\
y_{k}, s_{i}^{+}, s_{r}^{-} \geq 0,
\end{gathered}
$$

where $w_{0}, \lambda_{k}, s_{i}^{+}, s_{r}^{-}$are dual variables. Dual variable $\lambda_{k}$ limits efficiency of each DMU to not greater than one. The positive value of $\lambda_{k}$ in the dual identifies the benchmark or a peer group for inefficient DMU. This DEA CCR model assumes to be an input-oriented CRS model in which the input level is minimized as much as possible by keeping the current output level. The efficient target can be obtained as follows:

$$
\begin{aligned}
& x_{i k}^{\prime}=\phi x_{i k}-s_{i}^{-}, i=1, . ., m \\
& y_{i k}^{\prime}=\phi y_{r k}+s_{i}^{+}, r=1, \ldots, s
\end{aligned}
$$

From Eq. (9-14), it is clear that $\mathrm{DMU}_{\mathrm{k}}$ is efficient if and only if $\phi=1$, and $s_{i}^{-}=s_{i}^{+}=0$ for all $\mathrm{i}$ and $\mathrm{k}$ and inefficient if and only if $\phi=0$, and $s_{i}^{-} \neq 0, s_{i}^{+} \neq 0$ for all $\mathrm{i}$ and $\mathrm{k}$ where an asterisk denotes a solution value in an optimal solution.

\subsection{Input and output variables selection}

Out of many variables of the quality system, a consensus decision is taken on selecting five most critical variables - such as manpower, maintenance, training of employees, quality and on-time delivery that prominently affect the current quality system of selected industries - as inputs and outputs for the DEA CCR model by conducting brainstorming session [58] with managers, supervisors and skilled manpower of all the selected DMUs. The description and unit of selected inputs and outputs are given in Table 1.

\subsection{Data collection and data analysis}

For selected inputs and outputs, the data is recorded from different concern departments of the all selected DMUs over a period of six months (Table 2). The analysis of collected data is done by calculating correlation coefficients for all inputs and outputs as shown in Table 3. Input X3 is excluded due to a high value of correlation coefficient (0.55) against output Y2 [59-62]. The finally selected inputs and outputs for the DEA model under the study are shown in Fig. 1. 
Table 1 Input and output description and units

\begin{tabular}{|c|c|c|c|}
\hline $\begin{array}{l}\text { Variable } \\
\text { Type }\end{array}$ & $\begin{array}{l}\text { Name of } \\
\text { Variables / } \\
\text { Notation }\end{array}$ & Unit & Description \\
\hline \multirow[t]{3}{*}{ Input } & $\begin{array}{l}\text { Manpower } \\
\text { (X1) }\end{array}$ & Numbers & $\begin{array}{l}\text { Total number of employees in quality department. } \\
\text { The manpower data was collected from human resource } \\
\text { management (HRM) department of all selected DMUs. }\end{array}$ \\
\hline & $\begin{array}{l}\text { Maintenance } \\
\text { (X2) }\end{array}$ & Percentage & $\begin{array}{l}\text { Machine maintenance time/ Planned production time } * 100 \\
\text { The machine maintenance data was obtained from } \\
\text { production and maintenance departments. }\end{array}$ \\
\hline & $\begin{array}{l}\text { Training to } \\
\text { employees } \\
\text { (X3) }\end{array}$ & Hours & $\begin{array}{l}\text { Total monthly training imparted in hours/numbers of } \\
\text { employees } * 100 \\
\text { Training data was obtained from HRM departments of all } \\
\text { selected DMUs. }\end{array}$ \\
\hline \multirow[t]{2}{*}{ Output } & $\begin{array}{l}\text { Quality } \\
\text { (Y1) }\end{array}$ & Percentage & $\begin{array}{l}\text { Number of quality product in a lot/ Lot size*100 } \\
\text { The data was collected from final inspection departments } \\
\text { of selected DMUs. }\end{array}$ \\
\hline & $\begin{array}{l}\text { On-time } \\
\text { delivery } \\
\text { (Y2) }\end{array}$ & Percentage & $\begin{array}{l}\text { Number of on-time deliveries/ Total number of deliveries } \\
\text { made*100 } \\
\text { The data was obtained from marketing departments of all } \\
\text { selected DMUs. }\end{array}$ \\
\hline
\end{tabular}

\subsection{Model selection}

The DEA CCR model with CRS is proposed to evaluate the quality performance of the selected DMUs. The inputs (X1 \& X2) and outputs (Y1 \& Y2) are used to compute the efficiency score of the selected DMUs, set the benchmark or peer groups for inefficient DMUs, and measure the percentage of potential improvements by using output oriented optimization mode (maximized output).

The model facilitates the Lean-Kaizen concept implementation for the selected DMUs to be efficient.

Table 2 Value of inputs and outputs

\begin{tabular}{cccccc}
\hline DMU Names & \multicolumn{3}{c}{ Inputs } & \multicolumn{2}{c}{ Outputs } \\
\cline { 2 - 4 }$(1)$ & $\mathrm{X} 1$ & $\mathrm{X} 2$ & $\mathrm{X} 3$ & Y1 & $\mathrm{Y} 2$ \\
& $(2)$ & $(3)$ & $(4)$ & $(5)$ & $(6)$ \\
\hline DMU-1 & 8 & 4.32 & 103 & 55.22 & 98 \\
DMU-2 & 11 & 16.87 & 92 & 66.89 & 85 \\
DMU-3 & 25 & 5.59 & 72 & 71.03 & 81 \\
DMU-4 & 10 & 18.27 & 111 & 79.04 & 74 \\
DMU-5 & 27 & 2.67 & 92 & 73.08 & 73 \\
DMU-6 & 27 & 18.98 & 56 & 93.22 & 69 \\
DMU-7 & 5 & 1.09 & 98 & 95.11 & 96 \\
DMU-8 & 27 & 22.98 & 81 & 65.35 & 75 \\
DMU-9 & 9 & 2.98 & 89 & 72.98 & 89 \\
DMU-10 & 15 & 11.69 & 70 & 71.56 & 66 \\
Maximum & $\mathbf{2 7}$ & $\mathbf{2 2 . 9 8}$ & $\mathbf{1 1 1}$ & $\mathbf{9 5 . 1 1}$ & $\mathbf{9 8}$ \\
Minimum & $\mathbf{5}$ & $\mathbf{1 . 0 9}$ & $\mathbf{5 6}$ & $\mathbf{5 5 . 2 2}$ & $\mathbf{6 6}$ \\
Average & $\mathbf{1 6 . 4}$ & $\mathbf{1 0 . 5 4}$ & $\mathbf{7 8 . 5}$ & $\mathbf{7 4 . 3 5}$ & $\mathbf{8 0 . 6}$ \\
\hline
\end{tabular}


Table 3 Correlation coefficients of selected inputs and outputs

\begin{tabular}{ccc}
\hline Inputs/ Outputs & Y1 & Y2 \\
\hline X1 & 0.011031087 & -0.667480965 \\
X2 & -0.00814726 & -0.572696089 \\
X3 & -0.243145823 & 0.55394473 \\
\hline
\end{tabular}

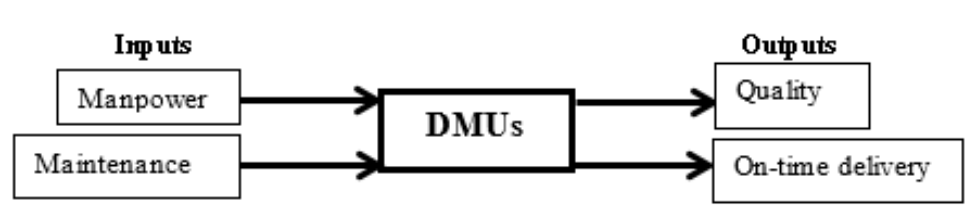

Fig. 1 Selected inputs and outputs for DEA Model

\section{IDENTIFICATION OF PERCENTAGE IMPROVEMENT IN QUALITY SYSTEM}

The collected data shown in Table 2 is analyzed by the DEA CCR model with CRS for objective function as output maximization in order to identify the percentage of improvement scope in the existing quality system of all selected DMUs. The efficiency scores of the selected DMUs are calculated by maximizing the output variables for the same set of input variables.

After the DEA analysis, Table 4 shows that DMU-7 obtained 100\% efficiency score and is the benchmark for rest of all selected DMUs. The actual value, target value and potential improvements of chosen inputs/outputs of the selected DMUs are clearly recorded in Table 5 for maximizing outputs strategy. A brief summary of recorded observations are as the following:

- DMU-7 scored 100\% efficiency hence improvement recommendation is zero.

- DMU-1 and DMU-9 recorded recommended improvement in output (Y2) by $56.73 \%$ and $94.16 \%$, respectively, which are easy to achieve. Similarly, DMU-2, DMU-3, DMU-4, DMU-5, DMU-6, DMU-8 \& DMU-10 recorded recommended improvement in output more than $100 \%$ which required to pay more attention to achieve these improvements.

Table 4 DEA efficiency scores for all selected DMUs

\begin{tabular}{ccccc}
\hline $\begin{array}{c}\text { DMU } \\
\text { Name }\end{array}$ & $\begin{array}{c}\text { DEA Efficiency Score } \\
(\%)\end{array}$ & Rank & $\begin{array}{c}\text { Peer/ Benchmark } \\
\text { DMUs }\end{array}$ & $\begin{array}{c}\text { Total } \\
\text { Peers }\end{array}$ \\
\hline DMU-7 & 100 & 1 & DMU-7 & 1 \\
DMU-1 & 63.80 & 2 & DMU-7 & 1 \\
DMU-9 & 51.50 & 3 & DMU-7 & 1 \\
DMU-4 & 41.60 & 4 & DMU-7 & 1 \\
DMU-2 & 40.20 & 5 & DMU-7 & 1 \\
DMU-5 & 31.40 & 6 & DMU-7 & 1 \\
DMU-10 & 25.10 & 7 & DMU-7 & 1 \\
DMU-6 & 18.20 & 8 & DMU-7 & 1 \\
DMU-3 & 16.90 & 9 & DMU-7 & 1 \\
DMU-8 & 14.50 & 10 & DMU-7 & 1 \\
\hline
\end{tabular}


These opportunities of improvements identified in the selected DMUs are taken into consideration for applying the Lean-Kaizen concept and an attempt is made to make them $100 \%$ efficient.

Table 5 Recommendation for improvement in selected DMUs

\begin{tabular}{|c|c|c|c|c|}
\hline \multirow[t]{2}{*}{$\mathrm{DMU}$} & \multirow{2}{*}{$\begin{array}{l}\text { Input/ } \\
\text { Output } \\
\text { variables }\end{array}$} & \multicolumn{3}{|c|}{ Objective function $=$ maximize output } \\
\hline & & $\begin{array}{c}\text { Actual } \\
\text { value }\end{array}$ & $\begin{array}{l}\text { Target } \\
\text { value }\end{array}$ & $\begin{array}{c}\text { Potential } \\
\text { Improvement } \\
\text { Percentage }\end{array}$ \\
\hline \multirow[t]{4}{*}{ DMU-7 } & $\mathrm{X} 1$ & 5 & 5 & $0.00 \%$ \\
\hline & $\mathrm{X} 2$ & 1.09 & 1.09 & $0.00 \%$ \\
\hline & Y1 & 95.11 & 95.11 & $0.00 \%$ \\
\hline & Y2 & 96 & 96 & $0.00 \%$ \\
\hline \multirow[t]{4}{*}{ DMU-1 } & $\mathrm{X} 1$ & 8 & 8 & $0.00 \%$ \\
\hline & $\mathrm{X} 2$ & 4.32 & 1.78 & $-59.83 \%$ \\
\hline & Y1 & 55.22 & 152.18 & $175.58 \%$ \\
\hline & $\mathrm{Y} 2$ & 98 & 153.6 & $56.73 \%$ \\
\hline \multirow[t]{4}{*}{ DMU-9 } & $\mathrm{X} 1$ & 9 & 9 & $0.00 \%$ \\
\hline & $\mathrm{X} 2$ & 2.98 & 1.96 & $-34.16 \%$ \\
\hline & Y1 & 72.98 & 171.2 & $134.58 \%$ \\
\hline & Y2 & 89 & 172.8 & $94.16 \%$ \\
\hline \multirow[t]{4}{*}{ DMU-4 } & $\mathrm{X} 1$ & 10 & 10 & $0.00 \%$ \\
\hline & $\mathrm{X} 2$ & 18.27 & 2.18 & $-88.07 \%$ \\
\hline & Y1 & 79.04 & 190.22 & $140.66 \%$ \\
\hline & Y2 & 74 & 192 & $159.46 \%$ \\
\hline \multirow[t]{4}{*}{ DMU-2 } & $\mathrm{X} 1$ & 11 & 11 & $0.00 \%$ \\
\hline & $\mathrm{X} 2$ & 16.87 & 2.40 & $-85.79 \%$ \\
\hline & Y1 & 66.89 & 209.24 & $212.82 \%$ \\
\hline & Y2 & 85 & 211.2 & $148.47 \%$ \\
\hline \multirow[t]{4}{*}{ DMU-5 } & $\mathrm{X} 1$ & 27 & 12.25 & $-54.64 \%$ \\
\hline & $\mathrm{X} 2$ & 2.67 & 2.67 & $0.00 \%$ \\
\hline & Y1 & 73.08 & 513.59 & $602.78 \%$ \\
\hline & Y2 & 73 & 518.4 & $610.14 \%$ \\
\hline \multirow[t]{4}{*}{ DMU-10 } & $\mathrm{X} 1$ & 15 & 15 & $0.00 \%$ \\
\hline & $\mathrm{X} 2$ & 11.69 & 3.27 & $-72.03 \%$ \\
\hline & Y1 & 71.56 & 266.25 & $272.07 \%$ \\
\hline & $\mathrm{Y} 2$ & 66 & 268.74 & $307.18 \%$ \\
\hline \multirow[t]{4}{*}{ DMU-6 } & $\mathrm{X} 1$ & 27 & 27 & $0.00 \%$ \\
\hline & $\mathrm{X} 2$ & 18.98 & 5.89 & $-68.99 \%$ \\
\hline & Y1 & 93.22 & 513.59 & $450.95 \%$ \\
\hline & Y2 & 69 & 518.4 & $651.30 \%$ \\
\hline \multirow[t]{4}{*}{ DMU-3 } & $\mathrm{X} 1$ & 25 & 25 & $0.00 \%$ \\
\hline & $\mathrm{X} 2$ & 5.59 & 5.45 & $2.50 \%$ \\
\hline & Y1 & 71.03 & 474.75 & $568.37 \%$ \\
\hline & $\mathrm{Y} 2$ & 81 & 479.19 & $491.59 \%$ \\
\hline \multirow[t]{4}{*}{ DMU-8 } & X1 & 27 & 27 & $0.00 \%$ \\
\hline & $\mathrm{X} 2$ & 22.98 & 5.89 & $-74.39 \%$ \\
\hline & Y1 & 65.35 & 513.59 & $685.91 \%$ \\
\hline & Y2 & 75 & 518.4 & $591.20 \%$ \\
\hline
\end{tabular}




\section{LEAN-KAIZEN IMPLEMENTATION}

Through the observations recorded in Table 5, DMU-1, DMU-2, DMU-3, DMU-4, DMU5, DMU-6, DMU-8, DMU-9, and DMU-10 are identified for deficiency in outputs (Y1 \& Y2) which need to be improved. The benchmark DMU-7 has been visited in search of improvement factors that make the industry $100 \%$ efficient. Then inefficient DMUs are further visited in order to collect data so that the required changes/ improvements in the quality system can be achieved. The '5-why' analysis is applied to identify the root cause of deficient output in selected departments of inefficient DMUs (Table 6).

\subsection{Kaizen events for output maximization}

After identifying the root cause of the deficient outputs, four Kaizen events are proposed as a solution for output maximization.

Table 6 Root cause analysis for deficient outputs

\begin{tabular}{|c|c|c|c|c|}
\hline $\begin{array}{l}\text { 5-Why } \\
\text { Analysis }\end{array}$ & $\begin{array}{l}\text { Deficiency in } \mathrm{Y} 2 \\
\text { in production } \\
\text { planning and } \\
\text { control } \\
\text { department }\end{array}$ & $\begin{array}{l}\text { Deficiency in } \mathrm{Y} 2 \text { in } \\
\text { production planning } \\
\text { and control } \\
\text { department }\end{array}$ & $\begin{array}{l}\text { Deficiency in Y1 in } \\
\text { packing department }\end{array}$ & $\begin{array}{l}\text { Deficiency in Y1 } \\
\text { in quality } \\
\text { department }\end{array}$ \\
\hline Why 1 & $\begin{array}{l}\text { Improper } \\
\text { material storage }\end{array}$ & $\begin{array}{l}\text { Delay in material } \\
\text { movement }\end{array}$ & $\begin{array}{l}\text { Variable packed } \\
\text { quality of finished } \\
\text { products }\end{array}$ & $\begin{array}{l}\text { Complexity in } \\
\text { identification of } \\
\text { material grade of } \\
\text { similar products }\end{array}$ \\
\hline Why 2 & $\begin{array}{l}\text { Conventional } \\
\text { drum used for } \\
\text { material storage }\end{array}$ & $\begin{array}{l}\text { Long path for } \\
\text { material movement }\end{array}$ & $\begin{array}{l}\text { Non-equal quantity } \\
\text { was packed due to } \\
\text { manual weighing }\end{array}$ & $\begin{array}{l}\text { Identification } \\
\text { tags were } \\
\text { dissolved in the } \\
\text { material during } \\
\text { material } \\
\text { movement }\end{array}$ \\
\hline Why 3 & $\begin{array}{l}\text { Non- } \\
\text { standardized } \\
\text { material storage } \\
\text { process followed } \\
\text { by selected } \\
\text { DMUs }\end{array}$ & $\begin{array}{l}\text { Gangway available } \\
\text { for material transfer } \\
\text { within departments }\end{array}$ & $\begin{array}{l}\text { Conventional } \\
\text { method was } \\
\text { adopted due to } \\
\text { heavy quantity to } \\
\text { be packed for } \\
\text { customer }\end{array}$ & $\begin{array}{l}\text { Paper material } \\
\text { used for } \\
\text { Identification } \\
\text { token }\end{array}$ \\
\hline Why 4 & $\begin{array}{l}\text { No work } \\
\text { instruction was } \\
\text { given to trace } \\
\text { material for } \\
\text { movement }\end{array}$ & $\begin{array}{l}\text { In-house work area } \\
\text { distribution of } \\
\text { selected DMUs }\end{array}$ & $\begin{array}{l}\text { On-time delivery to } \\
\text { customer pressurize } \\
\text { manpower for } \\
\text { quick packing }\end{array}$ & $\begin{array}{l}\text { No alternate } \\
\text { provision was } \\
\text { found for change } \\
\text { of identification } \\
\text { token }\end{array}$ \\
\hline Why 5 & $\begin{array}{l}\text { Sharp corners } \\
\text { led to delay in } \\
\text { receiving } \\
\text { material for } \\
\text { processing }\end{array}$ & $\begin{array}{l}\text { No alternative was } \\
\text { presented for the } \\
\text { shortest path. }\end{array}$ & $\begin{array}{l}\text { Lack of technology } \\
\text { for packing equal } \\
\text { quantity } \\
\text { automatically }\end{array}$ & $\begin{array}{l}\text { Identification tag } \\
\text { problem }\end{array}$ \\
\hline
\end{tabular}


Two Kaizen events were performed by brainstorming technique [63] in production planning and control (PPC) department for maximizing Y2 and two Kaizen events were conducted by using poka-yoke method [64] in packing and quality departments for maximizing Y1 of the selected DMUs.

Kaizen Event 1 \& 2: Maximizing Y2 in PPC department of DMU-1 and DMU-9 through brainstorming technique. The brainstorming technique was performed in which all the participants (managers, supervisors, and workers) of DMU-1 and DMU-9 provided ideas of improvements that enhance on-time delivery of products. Out of these ideas, rectangular trays with traceable numbers and broken walls for the shortest route were selected and recommended for implementation in respective DMUs.

Implementation of Kaizen event 1: Provided rectangular trays to improve Y2. The activity of material movement was critically analyzed within departments of DMU-1 and DMU-9; it is observed that PPC is using conventional drums for moving material from one department to another due to the lack of management awareness, communication and operator's negligence. The stored quantity and traceability of material were major issues while transferring material by PPC supervisors. The problem was fixed by using new rectangular trays of identification number instead of using broken drums to move material within departments (Table 7).

Implementation of Kaizen Event 2: Removing walls for optimized material movement for improving $Y 2$. The shop floor of selected organization was critically analyzed in identifying the shortest route for material transportation. The problem was fixed by eliminating the walls across departments in order to eliminate waste such as unnecessary transportation of material and improved on-time delivery within departments. The shortest path was selected by removing the wall of forging department. The broken walls were repaired and made available for the gangway (Table 7).

Kaizen Event 3 \& 4: Maximizing Y1 in DMU-2, DMU-3, DMU-4, DMU-5, DMU-6, DMU-8 and DMU-10 through Poka-yoke. Poka-yoke is the process which activates inventions that can perceive an abnormal situation before it occurs in the process and if it occurs, the system will be stopped. In order to improve on-time delivery in the present case, the manual weighing process is critically observed and an auto counter and feeder machine is recommended for product packing (Kaizen events 3). A program of equal quality packets is planned, prepared and installed within the machine in order to pack the same set of packets. In the case of noticing unequal quality of packing in the packet, the machine will automatically stop for manual inputs. In addition, engraved plastic tokens of different colors and names for various grades are recommended to avoid mixing of materials within departments as caused by the workers (Kaizen events 4). The colors of plastic tokens are selected as green for 'OK', yellow for 'Non-conformities' and red for 'Scrap' material for movement within departments. These various grades engraved in golden color on plastic tokens are suggested for the sake of their great visibility by workers. The material will be immediately stopped for sorting if it carries a wrong plastic token (Table 7).

Implementation of Kaizen events 3: Using Auto Counter and Feeder machine in packing department to improve Y1. The personal visit to packing department was made for critical analysis of the manual weighing process. It was found that there is a lack of technology in packing department for packing of an equal quantity of finished products to the customer. The problem was fixed by adding packing program to the auto counter and feeder machine. In order to improve on-time delivery of product, five successful run trails of a 
packing program for a set of 10 packets of 100 products (each) were performed. The new process of packing products was included in standardized work instruction and recommended to be followed by the packing department (Table 7).

Table 7 Implementation of recommended Kaizen events in the selected DMUs

\begin{tabular}{|c|c|c|c|}
\hline $\begin{array}{c}\text { Kaizen } \\
\text { Event / } \\
\text { Variables }\end{array}$ & $\begin{array}{l}\text { Selected } \\
\text { DMUs/ } \\
\text { Dept. }\end{array}$ & $\begin{array}{l}\text { Current situation of } \\
\text { selected DMUs (Before } \\
\text { Kaizen) }\end{array}$ & $\begin{array}{l}\text { Improved situation of selected } \\
\text { DMUs (After Kaizen) }\end{array}$ \\
\hline \multirow[t]{2}{*}{$1 . / \mathrm{Y} 2$} & $\begin{array}{l}1,9 / \\
\text { Production } \\
\text { Planning and } \\
\text { Control }\end{array}$ & & \\
\hline & & $\begin{array}{l}\text { Non-standardized } \\
\text { material stored in the } \\
\text { drums }\end{array}$ & $\begin{array}{l}\text { Rectangular trays replaced the } \\
\text { drums for material movement }\end{array}$ \\
\hline \multirow[t]{2}{*}{ 2. / Y2 } & $\begin{array}{l}1,9 / \\
\text { Production } \\
\text { Planning and } \\
\text { control }\end{array}$ & $\begin{array}{l}\text { Long route for material } \\
\text { movement. }\end{array}$ & \\
\hline & & & $\begin{array}{l}\text { One new door opened from } \\
\text { the main gangway side. }\end{array}$ \\
\hline \multirow[t]{2}{*}{$3 . / Y 1$} & $\begin{array}{l}2,3,4,5,6 \\
8,10 / \\
\text { Packing }\end{array}$ & $\begin{array}{l}\text { The conventional } \\
\text { weighing balance was } \\
\text { used to weigh the } \\
\text { packed components. }\end{array}$ & \\
\hline & & & $\begin{array}{l}\text { Auto counter \& feeder } \\
\text { installed to pack exact } \\
\text { quantity of material during } \\
\text { final packing. }\end{array}$ \\
\hline \multirow[t]{2}{*}{ 4. / Y1 } & $\begin{array}{l}2,3,4,5,6 \\
8,10 / \\
\text { Quality }\end{array}$ & $\begin{array}{l}\text { Complexity in the } \\
\text { identification of grades } \\
\text { of the materials due to a } \\
\text { variety of similar } \\
\text { products on the same } \\
\text { line. This complexity }\end{array}$ & 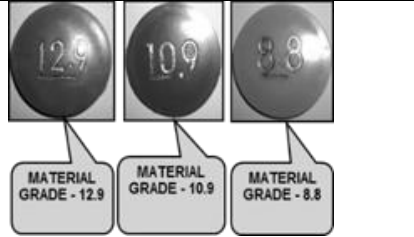 \\
\hline & & $\begin{array}{l}\text { created confusion for } \\
\text { packing and inspection } \\
\text { personals and led to } \\
\text { customer dissatisfaction. }\end{array}$ & $\begin{array}{l}\text { Engraved plastic tokens } \\
\text { (different colors/ name) for } \\
\text { identification eliminated the } \\
\text { confusion of similar products } \\
\text { of different grade. }\end{array}$ \\
\hline
\end{tabular}


Implementation of Kaizen events 4: Providing plastic tokens to improve Y1 in the quality department. The mixing of different grade material caused a considerable delay in moving material within the departments. The problem was fixed by implementing colored plastic tokens engraved grades for material movement. The quality supervisors were trained to issue new plastic tokens of the same material grade after each first approval of the products. The new process of issuing colored plastic tokens was added in standardized work instruction and recommended to be followed by the quality department (Table 7).

All the Kaizen events were accomplished within a period of two months in all the selected DMUs. Table 7 shows the implementation of the recommended Kaizen events in all inefficient DMUs.

\section{RESULTS ANALYSIS}

From the data collected and analyzed after each Kaizen event, in DMU-1 and DMU-9, the on-time delivery (Y2) of products within departments was improved by $33 \%-35 \%$ (with fine material traceability at all levels) which increased the working hours of these selected organizations. In addition, the automatic packing of exact quantity and correct material sent to customer improved quality (Y1) by $12 \%$ in DMU-1 and DMU-9. After successfully implementing the selected Kaizen events, the input and output data of all the selected DMUs were recorded.

Table 8 DEA efficiency score after Lean-Kaizen implementation

\begin{tabular}{lccccccc}
\hline DMU & X1 & X2 & Y1 & Y2 & $\begin{array}{c}\text { DEA Efficiency } \\
\text { Score }\end{array}$ & $\begin{array}{c}\text { Improvement } \\
\text { Percentage }\end{array}$ & Rank \\
\hline DMU-7 & 8 & 4.32 & 96 & 97 & $100 \%$ & $0 \%$ & 1 \\
DMU-1 & 5 & 1.09 & 98 & 100 & $100 \%$ & $36.20 \%$ & 2 \\
DMU-9 & 9 & 2.98 & 97.12 & 100 & $100 \%$ & $48.50 \%$ & 3 \\
DMU-5 & 11 & 16.87 & 89 & 73 & $95.30 \%$ & $63.90 \%$ & 4 \\
DMU-2 & 10 & 18.27 & 67.72 & 85 & $46.50 \%$ & $6.30 \%$ & 5 \\
DMU-4 & 15 & 11.69 & 81 & 74 & $41.80 \%$ & $0.20 \%$ & 6 \\
DMU-3 & 27 & 2.67 & 90.08 & 82 & $38.90 \%$ & $22.00 \%$ & 7 \\
DMU-10 & 27 & 18.98 & 75 & 68 & $26.80 \%$ & $1.70 \%$ & 8 \\
DMU-6 & 25 & 5.59 & 97.12 & 69 & $21.00 \%$ & $2.80 \%$ & 9 \\
DMU-8 & 27 & 22.98 & 78.11 & 76 & $15.90 \%$ & $1.40 \%$ & 10 \\
\hline
\end{tabular}

After analysis of recorded data and further application of the DEA CCR model, the results are presented in Table 8 which clearly indicates that DMU-7 is still 100\% efficient and is also appeared as a benchmark for rest of DMUs. DMU-1 and DMU-9 have become $100 \%$ efficient and gained $36.20 \%$ and $48.50 \%$ improvements, respectively. 
From further analysis of collected data, the reasons to become $100 \%$ efficient of DMU1 and DMU-9 are found as management awareness and willingness of employees to follow the standardized work instructions which were prepared after the application of Kaizen events. Additionally, the reasons to gain $8 \%$ to $49 \%$ improvements in the efficiency score of in DMU-2, DMU-3, DMU-4, DMU-5, DMU-6, DMU-8 and DMU-10 are observed as a lack of management support and worker's negligence in order to follow new standardized work instructions while performing forging as well as plating processes. Fig. 2 shows efficiency scores of quality system in all selected DMUs before and after Kaizen events implementation.

\section{CONCLUSIONS}

In this research paper, the Lean-Kaizen concept using the DEA CCR model is applied in order to improve the quality system of ten small scale fastener industries. Four Kaizen events have been proposed and implemented to eliminate waste in outputs (quality, ontime delivery) that consequently improved the efficiency score of quality system of the selected DMUs. The integration of Lean-Kaizen concept with the DEA CCR model is found to be an effective tool in identifying the potential improvements in inefficient firms which can be learned and achieved from benchmark/peer industries (most efficient). The efforts have been made to minimize or eliminate errors arising out of it.

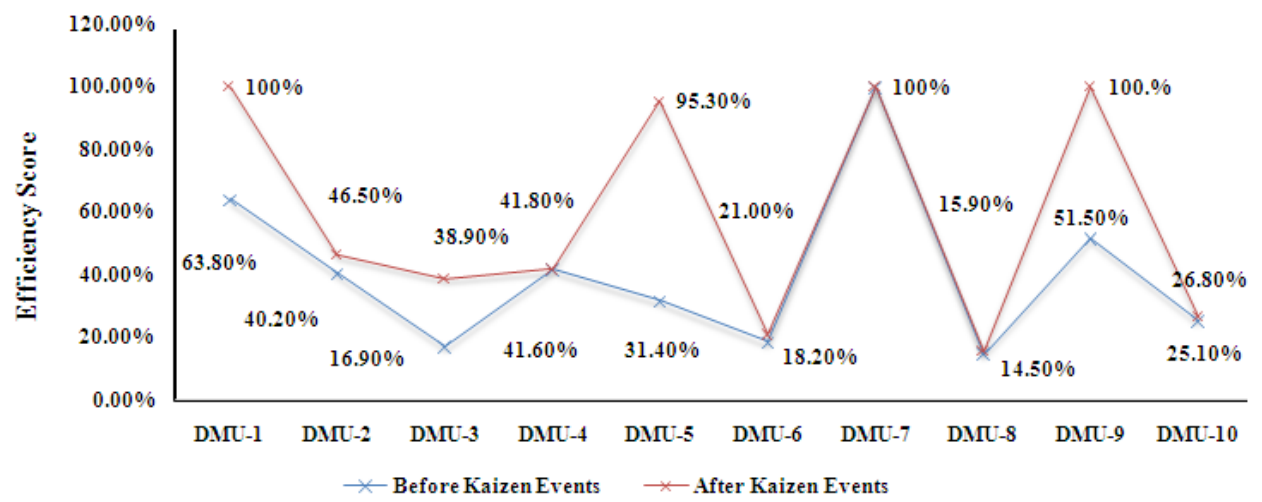

Fig. 2 Efficiency score of all DMUs before and after Kaizen events

This study can be further explored to optimize the results by collecting data after the Kaizen events implementation in all the selected industries. A further comparison can be made by the DEA CCR model in order to find new benchmarks/ peers so that new improvements can be achieved by applying strategies of outputs maximization. The main drawback of this approach is that it does not clarify the number of steps that needs to be taken to obtain an optimized result. The identification and implementation of improvement opportunities are dependent on individual skill and experience. This framework can also be implemented to measure the performance of production, maintenance, and quality of the industries producing different products and ready to adopt the Lean-Kaizen concept across all levels of the organization. The study concluded that the Lean-Kaizen using DEA is an efficient technique for improvement in the quality system of the organizations. 


\section{REFERENCES}

1. Panwar, Avinash, Jain, Rakesh, and Rathore, A.P.S., 2015, Lean implementation in Indian process industries - some empirical evidence, Journal of Manufacturing Technology Management, 26(1), pp. $131-160$.

2. Singh, B., Garg, S. K., and Sharma, S. K., 2010, Scope for lean implementation: a survey of 127 Indian industries, International Journal of Rapid Manufacturing, 1(3), pp. 323-333.

3. Bhuiyan, N., and Baghel, A., 2005, An overview of continuous improvement: from the past to the present, Management Decision, 43(5), pp. 761-771.

4. Suarez-Barraza, M. F., Smith, T., and Dahlgaard-Park, S. M., 2009, Lean-kaizen public service: an empirical approach in Spanish local governments, The TQM Journal, 21(2), pp. 143-167.

5. Prashar, Anupama, 2014, Redesigning an assembly line through Lean-Kaizen: an Indian case, The TQM Journal, 26(5), pp. 475-498

6. Suarez-Barraza, M. F., Ramis-Pujol, J., and Kerbache, L., 2011, Thoughts on kaizen and its evolution: Three different perspectives and guiding principles, International Journal of Lean Six Sigma, 2, pp. 288-308.

7. Liker, J. K., 2004, The Toyota Way, McGraw-Hill, New York, NY.

8. Singh, Bhim, Garg, S.K., and Sharma, S. K., 2010, Development of index for measuring leanness: study of an Indian auto component industry, Measuring Business Excellence, 14(2), pp. 46-53.

9. Charnes, A., Cooper, W. W., Lewin, A. Y., and Seiford, Lawrence M., 1994, Data Envelopment Analysis: Theory, Methodology and Application. Kluwer Academic Publisher, Boston, MA.

10. Gondhalekar, Shrinivas, Babu, A. Subhash, and Godrej, N.B., 1995, Towards TQM using kaizen process dynamics: a case study, International Journal of Quality \& Reliability Management, 12(9), pp. 192-209.

11. Singh, J., and Singh, H., 2012, Continuous improvement approach: state-of-art review and future implications, International Journal of Lean Six Sigma, 3(2), pp. 88-111.

12. Shah, R., and Ward, P. T., 2003, Lean manufacturing: context, practice bundles, and performance, Journal of Operations Management, 21(2), pp. 129-149.

13. Suarez-Barraza, M. F., Ramis-Pujol, J., and Dahlgaard-Park, S., 2013, Changing quality of life through the Personal Kaizen approach: a qualitative study, International Journal of Quality and Service Sciences, 5(2), pp. 191-207.

14. Imai, M., 1986, KAIZEN: The Key to Japans Competitive Success, McGraw-Hill, New York, NY.

15. Darlington, J., Francis, M., Found, P., and Thomas, A., 2015, Targeting lean process improvement projects for maximum financial impact, Production Planning \& Control, 27(2), pp. 114-132.

16. Shang, G., and Pheng, L. S., 2013, Understanding the application of Kaizen methods in construction firms in China, Journal of Technology Management in China, 8(1), pp. 18-33.

17. Ohno, T., 1988, Toyota production system: beyond large-scale production, CRC Press.

18. Vinodh, S., Arvind, K. R., and Somanaathan, M., 2011, Tools and techniques for enabling sustainability through lean initiatives, Clean Techn Environ Policy, 13, pp. 469-479.

19. Jadhav, J. R., Mantha, S. S., and Rane, S. B., 2015, Roadmap for Lean implementation in Indian automotive component manufacturing industry: comparative study of UNIDO Model and ISM Model, Journal of Industrial Engineering International, 11(2), pp. 179-198.

20. Mourtzis, D., Papathanasiou, P., and Fotia, S., 2016, Lean Rules Identification and Classification for Manufacturing Industry, Procedia CIRP, 50, pp. 198-203.

21. Womack, J.P., Jones, D.T. and Roos, D., 1990, The machine that changed the world, Simon and Schuster.

22. Dorota Rymaszewska, A., 2014, The challenges of lean manufacturing implementation in SMEs, Benchmarking: An International Journal, 21(6), pp. 987-1002.

23. Wu, P., Low, S. P., and Jin, X., 2013, Identification of non-value adding NVA activities in precast concrete installation sites to achieve low-carbon installation, Resources, Conservation and Recycling, 81, pp. 60-70.

24. Kumar, M., Khurshid, K. K., and Waddell, D., 2014, Status of Quality Management practices in manufacturing SMEs: a comparative study between Australia and the UK, International Journal of Production Research, 52(21), pp. 6482-6495.

25. Liker, J., 2006, The Toyota way field book, Esensi.

26. Achanga, P., Shehab, E., Roy, R., and Nelder, G., 2006, Critical success factors for lean implementation within SMEs, Journal of Manufacturing Technology Management, 17(4), pp. 460-471. 
27. Farris, J. A., Van Aken, E. M., Doolen, T. L., and Worley, J., 2009, Critical success factors for human resource outcomes in Kaizen events: An empirical study, International Journal of Production Economics, 117(1), pp. 42-65.

28. Garcia, J. L., Rivera, D. G., and Iniesta, A. A., 2013, Critical success factors for Kaizen implementation in manufacturing industries in Mexico, International Journal of Advanced Manufacturing Technology, 68(1-4), pp. 537-545.

29. Rivera-Mojica, D., and Rivera-Mojica, L., 2014, Critical success factors for kaizen implementation, Lean manufacturing in the Developing, pp. 157-178.

30. Moeuf, A., Tamayo, S., Lamouri, S., Pellerin, R., Lelievre, A., and Montreal, P., 2016, Strengths and weaknesses of small and medium sized enterprises regarding the implementation of lean manufacturing, Management and Control MIM 2016, 49(12), pp. 71-76.

31. Eaidgah, Y., Kurczewksi, K., Abdekhodaee, A., and Maki, A. A., 2016, Visual management, performance management and continuous improvement: a lean manufacturing approach, International Journal of Lean Six Sigma, 7(2), pp. 187-210.

32. Suarez-Barraza, Manuel F., Ramis-Pujol, Juan, 2010, Implementation of Lean-Kaizen in the human resource service process: A case study in a Mexican public service organisation, Journal of Manufacturing Technology Management, 21(3), pp. 388-410.

33. Glover, Wiljeana J., Liu, Wen-Hsing, Farris, Jennifer A., and Aken, Eileen M. Van, 2013, Characteristics of established kaizen event programs: an empirical study, International Journal of Operations \& Production Management, 33(9), pp. 1166-1201.

34. Mishra, R. K., and Patel, G., 2009, Supplier Development Strategies : a Data Envelopment Analysis Approach, Intelligence, pp. 99-110.

35. Kuah C. T., Wong K. Y., and Behrouzi, Farzad, 2010, Application of Data Envelopment Analysis to Assess Quality Management Efficiency, World Academy of Science, Engineering and Technology, 4(10), pp. 651-656.

36. Xie, X.M., Zang, Z.P. and Qi, G.Y., 2016, Assessing the environmental management efficiency of manufacturing sectors: Evidence from emerging economies, Journal of Cleaner Production, 112, pp. 1422-1431.

37. Dabestani, R., Shahin, A., Saljoughian, M., and Shirouyehzad, H., 2016, Importance-performance analysis of service quality dimensions for the customer groups segmented by DEA, International Journal of Quality \& Reliability Management, 33(2), pp. 160-177.

38. Lau, Kwok Hung, 2012, Distribution network rationalisation through benchmarking with DEA, Benchmarking: An International Journal, 19(6), pp. 668-689.

39. Jafarpour, E. et al., 2015, Evaluation of the suggestions system performance using DEA, the case of Esfahan's Steel Company, International Journal of Productivity and Quality Management, 15(1), pp. 20-34.

40. Azadeh, A., Sheikhalishahi, M., Firoozi, M., and Khalili, S. M., 2013, An integrated multi-criteria taguchi computer simulation-DEA approach for optimum maintenance policy and planning by incorporating learning effects, International Journal of Production Research, 51(18), pp. 5374-5385.

41. Warning, S., 2014, How to pick your staff? Using data envelopment analysis, Management Research Review, 37(9), pp. 815-832.

42. Bian, Yiwen, $\mathrm{Hu}, \mathrm{Miao}$ and $\mathrm{Xu}$, Hao, 2015, Measuring efficiencies of parallel systems with shared inputs/ outputs using data envelopment analysis, Kybernetes, 44(3), pp. 336-352.

43. Wu, H., Lv, K., Liang, L., and Hu, H., 2015, Measuring performance of sustainable manufacturing with recyclable wastes: A case from Chinas iron and steel industry, Omega, pp. 1-10.

44. Emrouznejad, A., Rostami-Tabar, B., and Petridis, K., 2016, A novel ranking procedure for forecasting approaches using Data Envelopment Analysis, Technological Forecasting and Social Change, 111, pp. 235-243.

45. Amirteimoori, A., Despotis, D. and Kordrostami, S., 2014, Variables reduction in data envelopment analysis, Optimization, 63(5), pp.735-745.

46. Sevkli, M., Koh, S. C. L., and Zaim, S., 2007, An application of data envelopment analytic hierarchy process for supplier selection: a case study of BEKO in Turkey, International Journal of Production Research, 45(9), pp. 1973-2003.

47. Song, Chenxi, Li, Mingjia, Zhang, Fan, He, Yaling, and Tao, Wenquan, 2014, Analysis of Energy Efficiency for Coal-fired Power Units Based on Data Envelopment Analysis Model, Energy Procedia, 61, pp. 904-909.

48. Weber, Charles A., 1996, A data envelopment analysis approach to measuring vendor performance, Supply Chain Management: An International Journal, 1(1), pp. 28-39. 
49. Shorouyehzad, H., Hoseinzadeh Lotfi, F., Aryanezhad, M., and Dabestani, R., 2011, Efficiency and Ranking Measurement of Vendors by Data Envelopment Analysis, International Business Research, 4(2), pp. 137-146.

50. Mathiyalakan Sathasivam, and Chung, Chen, 1996, A DEA approach for evaluating quality circles, Benchmarking for Quality Management \& Technology, 3(3), pp. 59-70.

51. Fancello, G., Uccheddu, B., and Fadda, P., 2014, Data Envelopment Analysis D.E.A. for Urban Road System Performance Assessment, Procedia - Social and Behavioral Sciences, 111, pp. 780-789.

52. Goksen, Y., Dogan, O., and Ozkarabacak, B., 2015, A Data Envelopment Analysis Application for Measuring Efficiency of University Departments, Procedia Economics and Finance, 19, pp. 226-237.

53. Mogha, S. K., Yadav, S. P., and Singh, S. P., 2014, Estimating technical and scale efficiencies of private hospitals using a non-parametric approach: case of India, International Journal of Operational Research, 20(1), pp. 21-40.

54. Mogha, S. K., Yadav, S. P., and Singh, S. P., 2016, Estimating technical efficiency of public sector hospitals of Uttarakhand India, International Journal of Operational Research, 25(3), pp. 371-399.

55. Charnes, A., Cooper, W. W., and Rhodes, E., 1978, Measuring the efficiency of decision making units, European Journal of Operational Research, 2(6), pp. 429-444.

56. Sofianopoulou, S, 2006, Manufacturing cells efficiency evaluation using data envelopment analysis, Journal of Manufacturing Technology Management, 17(2), pp. 224-238.

57. Parthiban, P., Zubar, H. A., and Katakar, P., 2013, Vendor selection problem: a multi-criteria approach based on strategic decisions, International Journal of Production Research, 51(5), pp. 1535-1548.

58. Buggie, Frederick D., 2003, How to hold effective Brainstorming Sessions, Handbook of Business Strategy, 4(1), pp. 120-123.

59. Rust, Roland T., Stewart, Greg L., Miller, Heather, and Pielack, Debbie, 1996, The satisfaction and retention of frontline employees: A customer satisfaction measurement approach, International Journal of Service Industry Management, 7(5), pp. 62-80.

60. Liu, Jian, and Yu, De-jie, 2004, Evaluation of plant maintenance based on data envelopment analysis, Journal of Quality in Maintenance Engineering, 10(3), pp. 203-209.

61. Debnath, Roma Mitra, and Sebastian, V.J., 2014, Efficiency in the Indian iron and steel industry - an application of data envelopment analysis, Journal of Advances in Management Research, 11(1), pp. 4-19.

62. Amirteimoori, A., Despotis, D. K., and Kordrostami, S., 2012, Variables reduction in data envelopment analysis, Optimization, 63(5), pp. 735-745.

63. Karakas, F. and Kavas, M., 2008, Creative brainstorming and integrative thinking: skills for twentyfirst century managers, Development and Learning in Organizations: An International Journal, 22(2), pp. 8-11.

64. Fisher, Michael, 1999, Process improvement by poka-yoke, Work Study, 48(7), pp. 264-266. 